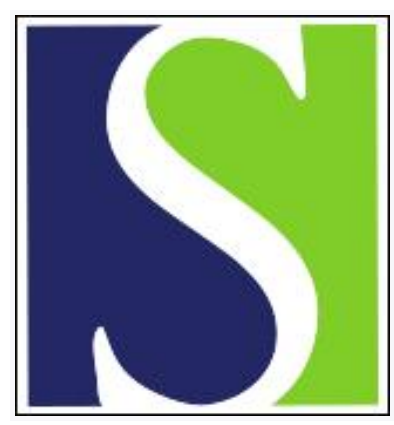

Scand J Work Environ Health 2000;26(1):67-70

https://doi.org/10.5271/sjweh.512

Issue date: Feb 2000

Serum concentrations of hexachlorobenzene in family members of workers in an electrochemical factory

by Ballester F, Sala M, Sunyer J, Grimalt J

Key terms: home contamination; organochlorine compound; para-occupational exposure; serum concentration

This article in PubMed: www.ncbi.nlm.nih.gov/pubmed/10744180

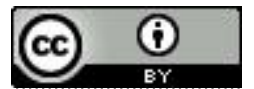




\title{
Serum concentrations of hexachlorobenzene in family members of workers in an electrochemical factory
}

\author{
by Ferran Ballester, MD, ${ }^{1,2}$ Maria Sala, MD, ${ }^{1}$ Jordi Sunyer, MD, ${ }^{1}$ Joan Grimalt, $P h D^{3}$
}

\begin{abstract}
Ballester F, Sala M, Sunyer J, Grimalt J. Serum concentrations of hexachlorobenzene in family members of workers in an electrochemical factory. Scand $J$ work Environ Health 2000;26(1):67-70.

Objectives This study analyzed the effect of living in the same household with a worker employed in an electrochemical factory on the hexachlorobenzene (HCB) concentrations of serum in the general population of Flix, Spain.

Methods A total of 608 subjects from the general population (response rate $42 \%$ ) completed a questionnaire about residence, occupation, life-styles, and medical history and provided blood samples. Among them, 412 had never worked in the electrochemical factory. Information about the occupation of the family members was completed, and the subjects were classified with the degree of relationship with the worker having been taken into account. A multiple linear regression analysis was conducted to model HCB serum for nonfactory workers.

Results Having a spouse who worked in the factory was associated with elevated $\mathrm{HCB}$ concentrations in serum. The adjusted relative increases were $1.28(\mathrm{P}=0.0004)$ and $1.23(\mathrm{P}=0.0022)$ times the corresponding value of people not living with workers of the factory, respectively for spouses of current and past workers. Relatives other than spouses did not show any increase.

Conclusions The results of this study suggest that, among nonworkers, living with a worker of the electrochemical factory in Flix is associated with an increase in concentrations of HCB in blood. These findings may suggest a source of exposure to HCB that has thus far not been studied and that could be important in populations not occupationally exposed to organochlorines.
\end{abstract}

Key terms home contamination, organochlorine compounds, para-occupational exposure, serum concentrations.

Hexachlorobenzene (HCB) is a chlorinated hydrocarbon, formerly used as a fungicide, that accumulates in the biological system. The major source of HCB contamination is industrial emission as a by-product related to the manufacture of organochlorinated products. Little information is available on the health effects of HCB exposure on humans, except from an earlier experience in Turkey $(1,2)$. Concern has spread that the health of workers' families may be adversely affected as a result of workers' exposure to hazardous substances. The adverse effects could be produced directly through genetic damage at conception or indirectly, when toxic substances are carried home on the bodies, clothing, or vehicles of workers $(3,4)$. This kind of exposure is known as "paraoccupational exposure" or "home contamination" (5), and examples of such exposure exist for lead (5), asbestos (6), beryllium, arsenic, Kepone $B^{\circ}$, synthetic estrogens, and polychlorinated compounds (4). No information is available on para-occupational exposure to hexachlorobenzene, but evidence from studies dealing with chlorinated solvents (4) would suggest that indirect exposure may occur more commonly than suspected. A study on the health effects of HCB has been carried out in Flix (Catalonia, Spain), a rural population highly exposed to $\mathrm{HCB}$ due to the presence of an electrochemical factory (7). In the present study we analyzed the effect of living

Research Unit of Environmental and Respiratory Health, Institut Municipal d'Investigació Mèdica-IMIM, Barcelona, Spain.

Unit of Epidemiology and Statistics, Institut Valencià d'Estudis en Salut Pública-IVESP, Valencia, Spain.

3 Department of Environmental Chemistry (CID-CSIC), Barcelona, Spain.

Reprint requests to: Dr Maria Sala, Research Unit of Environmental and Respiratory Health, Institut Municipal d'Investigació Mèdica-IMIM, C/ Doctor Aiguader 80 08003, Barcelona, Spain. [E-mail: msala@imim.es] 
with a worker of the electrochemical factory on the HCB serum concentrations of people who had never worked in this factory.

\section{Subjects and methods}

A cross-sectional study was carried out on the 4178 inhabitants over 14 years of age in Flix in June of 1994. The details have been reported elsewhere (7). Briefly, subjects from a random sample of this general population $(\mathrm{N}=777)$ were asked to provide blood samples and to answer a questionnaire about residence, occupation, life-style and medical history. The questionnaire was completed by 549 subjects ( $70.5 \%$ response rate), and 328 of the 549 gave blood samples ( $42.1 \%$ response rate). In addition, from the rest of this general population, 1251 subjects completed the questionnaire, 280 of whom also provided biological samples voluntarily. No differences were seen in the socioeconomic and occupational variables or the occurrence of chronic diseases between the subjects from the random samples with and without biological samples (eg, mean age 50.1 and 47.9 years, respectively) nor in the HCB serum concentrations between the 328 subjects of the random sample and the 280 volunteers (eg, geometric mean of HCB $16.9 \mathrm{ng} / \mathrm{ml}$ and 16.6 $\mathrm{ng} / \mathrm{ml}$, respectively). The present study was based on the 608 subjects who provided blood samples. Of them, 412 had never worked in the electrochemical factory, and 190 did not live with any worker of the factory.

Information about the occupation of the family members or subjects living with the 412 subjects included in the study was obtained through the questionnaire, and in
268 cases $(64 \%)$ it was validated against information obtained from the Primary Health Care Center and the Labor Union Committee of the factory. The agreement between these 2 sources classifying employment status in the electrochemical factory was fairly good [kappa index $0.78, \mathrm{P}<0.0001$, for agreement in 3 categories (current worker, past worker, never worker) and 0.83 , $\mathrm{P}<0.0001$, for agreement in 2 categories (ever worker, never worker). We classified the subjects who had never worked in the factory according to the degree of relationship with the worker and the occupational situation (spouse of a current worker, spouse of a former worker, other relatives of a current worker, other relatives of a former worker, with not living with a worker of the factory as the reference category). When a person lived with more than one worker $(\mathrm{N}=13,12$ with 2 relatives and 1 with 4) of the factory, the category of closest relationship was considered (the closest category being the spouse of a current worker).

The HCB serum concentrations were analyzed by a gas chromatograph coupled to an electron capture detector as previously described (8). The initial descriptive statistical parameters were computed. Because the distribution of the HCB serum concentrations was skewed to the right, natural logarithmic transformations were used in the analysis. A multiple linear regression analysis was conducted to model HCB serum for the nonworkers. On the basis of previous results on the determinants of $\mathrm{HCB}$ exposure in this population (9), the variables taken into account included gender, age (in years plus 2 dummy variables: $>64$ and $<26$ years), body mass index (in kilograms per square meter), loss of weight in the last 12 months (yes or no), consumption of fish caught in the local river (yes or no), residence (living closer than 1500

Table 1. Concentration of hexachlorobenzene $(\mathrm{HCB})$ in serum in a population $(\mathrm{N}=608)$ living near an electrochemical factory.

\begin{tabular}{|c|c|c|c|c|c|c|c|c|}
\hline & \multirow[t]{3}{*}{$N$} & \multicolumn{2}{|c|}{ Age (years) } & \multicolumn{5}{|c|}{ HCB concentration $(\mathrm{ng} / \mathrm{ml})$} \\
\hline & & \multirow[t]{2}{*}{ Mean } & \multirow[t]{2}{*}{ SD } & \multirow{2}{*}{$\begin{array}{l}\text { Geometric } \\
\text { mean }\end{array}$} & \multirow{2}{*}{$\begin{array}{l}\text { Maximum } \\
\text { value }\end{array}$} & \multicolumn{3}{|c|}{ Percentiles } \\
\hline & & & & & & 25 & 50 & 75 \\
\hline \multicolumn{9}{|l|}{ General population } \\
\hline Male & 249 & 50.2 & 17.7 & 21.5 & 1485 & 9.8 & 19.0 & 36.3 \\
\hline Female & 359 & 48.0 & 17.2 & 14.4 & 180 & 9.9 & 15.7 & 22.0 \\
\hline All & 608 & 48.9 & 17.4 & 17.0 & 1485 & 9.8 & 16.5 & 24.7 \\
\hline \multicolumn{9}{|l|}{ Non-factory workers } \\
\hline Male & 80 & 39.8 & 18.2 & 8.1 & 57.3 & 3.6 & 8.6 & 14.6 \\
\hline Female & 332 & 47.9 & 17.3 & 14.3 & 180 & 9.5 & 15.5 & 21.8 \\
\hline All & 412 & 46.3 & 17.7 & 12.8 & 180 & 8.2 & 14.4 & 20.9 \\
\hline \multicolumn{9}{|l|}{ Living with a worker of the factory } \\
\hline No & 190 & 46.8 & 18.4 & 11.2 & 92.3 & 7.6 & 12.3 & 17.3 \\
\hline Yes & 222 & 46.0 & 17.2 & 14.4 & 180 & 9.4 & 15.9 & 23.2 \\
\hline Spouse of a current worker & 73 & 39.3 & 8.5 & 15.0 & 180 & 10.8 & 14.4 & 21.1 \\
\hline Spouse of a former worker & 101 & 60.6 & 9.3 & 21.1 & 101 & 16.8 & 21.4 & 27.0 \\
\hline $\begin{array}{l}\text { Relative other than spouse } \\
\text { of a current worker }\end{array}$ & 17 & 20.4 & 3.6 & 5.3 & 10.8 & 3.5 & 6.3 & 8.0 \\
\hline $\begin{array}{l}\text { Relative other than spouse } \\
\text { of a former worker }\end{array}$ & 31 & 27.8 & 13.6 & 6.3 & 23.0 & 3.7 & 6.5 & 9.2 \\
\hline
\end{tabular}


meters from the factory or not), educational level (primary level or less versus secondary level or higher), use of pesticides (yes or no), and parity of women $(0,1,2$, and $\geq 3$ children). A core model was fitted for the HCB serum concentrations by entering the variables one by one. Variables with a P-value lower than 0.2 were kept in the core model. In a 2 nd step, variables related with the work of family members were introduced into the core model. A sensitivity analysis was carried out that took into account the condition of living with more than one worker of the factory. Analyses stratified by gender, age group $(<45,45-64, \geq 65$ years $)$, and sample group (random or not) were also performed.

\section{Results}

Table 1 shows the mean age and the crude distribution of the HCB concentrations in the serum of the studied population. Among the people not working in the factory the concentrations were higher in the women than in the men. The concentrations of subjects living with workers of the factory averaged $3 \mathrm{ng} / \mathrm{ml}$ higher (expressed as the geometric mean) than those of people not living together with a worker. The spouses of former workers were the group with the highest concentrations. Regarding age, relatives other than spouses tended to be younger, while the spouses of former workers tended to be older.

Table 2 presents the results of the multiple linear regression for the HCB concentration in the serum of people not working in the factory. The final model for the men and women together explained $58 \%$ of the variability of the HCB serum concentrations. Being the spouse of a worker of the factory was significantly associated with the HCB concentrations (adjusted relative increases of 1.28 and 1.23 times the corresponding value of people not living with workers of the factory for spouses of current and past workers, respectively). Being a relative other than a spouse was not associated with an increase. The relation was similar for both genders.

The sensitivity analysis taking into account the condition of living with more than one worker of the factory yielded the same results as those shown in table 2 . Among the women, the analysis stratifying by age group showed that the relationship was strongest among wives of current workers younger than 45 years of age (adjusted relative increase of $1.49, \mathrm{P}<0.0001$ ). The same analysis for men was not possible due to the small numbers. Finally, the stratified analysis by sample group (random or nonrandom) showed similar results for both groups.

\section{Discussion}

In this study we found an association between spouses living with workers of a electrochemical factory in Flix (Spain) and the HCB concentration in their blood serum. When a series of predictors of the $\mathrm{HCB}$ concentration were taken into account, the association was higher for spouses of current workers than for those of former workers. Other members of the family did not have an elevated HCB concentration in their blood. This finding suggests that important life-style factors, such as food, may not be an explanation for this finding. One hypothesis is that exhaled breath may be a cause of exposure to organic compounds (10). In a study simulating workers' exposure to perchloroethylene and modeling home concentrations, Thompson \& Evans (11) found that a worker's body burdens may be sufficient to explain elevated home concentrations. It is important to note that, in a preliminary study conducted in 4 houses in Flix, the concentrations of indoor $\mathrm{HCB}$ were much higher in the houses of workers than in those of nonworkers (unpublished data), and therefore workers seem to carry some pollution home, either by breath or by clothes.

Table 2. Associationa between living with a worker of an electrochemical factory and the concentration of hexachlorobenzene (HCB) (in In) in serum - multiple linear regression.

\begin{tabular}{|c|c|c|c|c|c|c|c|c|c|c|c|c|}
\hline \multirow{2}{*}{$\begin{array}{l}\text { Relationship with workers in same } \\
\text { household }{ }^{\mathrm{B}}\end{array}$} & \multicolumn{4}{|c|}{ Males } & \multicolumn{4}{|c|}{ Females } & \multicolumn{4}{|c|}{ Males and females combined } \\
\hline & N & Coefficient & SE & P-value & $\mathbf{N}$ & Coefficient & SE & $P$-value & N & Coefficient & $\mathrm{SE}$ & P-value \\
\hline Spouse of a current worker & 1 & 1.44 & 0.69 & 0.0399 & 72 & 0.23 & 0.07 & 0.0005 & 73 & 0.25 & 0.07 & 0.0004 \\
\hline Spouse of a former worker & 2 & 0.89 & 0.56 & 0.1179 & 99 & 0.18 & 0.06 & 0.0031 & 101 & 0.21 & 0.07 & 0.0022 \\
\hline $\begin{array}{l}\text { Relative other than spouse } \\
\text { of a current worker }\end{array}$ & 5 & 0.23 & 0.37 & 0.5324 & 12 & -0.07 & 0.16 & 0.6327 & 17 & 0.09 & 0.15 & 0.5427 \\
\hline $\begin{array}{l}\text { Relative other than spouse } \\
\text { of a former worker }\end{array}$ & 7 & 0.15 & 0.36 & 0.6726 & 24 & -0.10 & 0.11 & 0.3128 & 31 & -0.02 & 0.11 & 0.8503 \\
\hline Constant HCB levelsc & & 1.96 & 0.21 & . & & 2.40 & 0.08 & . & . & 2.11 & 0.08 & . \\
\hline Adjusted coefficient of determination & . & 0.45 & & . & . & 0.58 & & . & . & 0.58 & & . \\
\hline
\end{tabular}

a Adjusted for gender, age, body mass index, loss of weight, residence, educational level, and a dummy variable for a woman with 4 workers in her household. The use of pesticides and parity did not enter the model ( $P>0.2)$.

'Considering only the highest category of relationship for each person.

c HCB concentrations (in In) of nonfactory workers without family members in the electrochemical factory. 
The increase found represents around $25 \%$ of the average concentration in this general population of Flix, but in absolute terms it is a greater quantity than the mean of the HCB concentrations found in other general populations studied (12-14). As has been reported elsewhere (9), the serum HCB concentrations of this population, even of nonworkers, were the highest ever described. This fact may reflect inadequacies in the working processes of the factory.

No differences were observed between the subjects from the random and nonrandom samples, (7) and no differences were observed when the analysis was done separately for the 2 groups. A potential source of confounding could arise from direct exposure of spouses of workers in the buildings of the factory. Workers' relatives could enter the factory more often than nonrelatives, but this occurred rarely.

In conclusion, this study suggests that, among nonworkers, living with a worker of the electrochemical factory in Flix is associated with an increase in the HCB concentration in blood. This association is particularly notable for spouses of workers. What these results represent in terms of public health is not clear, but it merits being taken into account as a source of exposure to HCB, and probably other organochlorinated compounds, in nonoccupationally exposed populations.

\section{Acknowledgments}

This study was partially supported by a grant from the Fondo de Investigación Sanitaria (FIS), Ministry of Health, Spain, FIS: 93/0006-01, and by a grant from the Departament de Sanitat i Seguretat de Catalunya. Ferran Ballester received support from the Fondo de Investigación Sanitaria, BAE-FIS: 97/5261. The authors would like to thank Rosa Sabater and people working in the Primary Health Care Center of Flix and the local Labor Union Committee for their help in providing useful information and Dave McFarlane for his technical advice.

\section{References}

1. Cam C, Nigogosyan G. Acquired toxic Porphyria Cutanea Tarda due to hexachlorobenzene. JAMA 1963;183:88-91.

2. Peters HA, Gocmen A, Cripps DJ, Bryan GT, Dogramaci I. Epidemiology of hexachlorobenzene-induced porphyria in Turkey. Arch Neurol 1982;39:744 - 9.

3. Olshan AF, Faustman EM. Male-mediated developmental toxicity. Annu Rev Public Health 1993;14:159-81.

4. Knishkowy B, Baker EL. Transmission of occupational disease to family contacts. Am J Ind Med 1986;9:543-50.

5. Whelan EA. Elevated blood lead levels in children of construction workers. Am J Public Health 1997; 87:1352-5.

6. Anderson HA, Lilis R, Daum SM, Selikoff IJ. Asbestosis among household contacts of asbestos factory workers. Ann NY Acad Sci 1979;330:387—99.

7. Sala M, Sunyer J, Otero R, Santiago-Silva M, Ozalla D, Herrero C, et al. Health effects of chronic high exposure to hexachlorobenzene in a general population sample. Environ Health Perspect 1998;54:102—9.

8. Otero R, Santiago-Silva M, Grimalt JO. Hexachlorobenzene in human blood serum. J Chromatogr 1997;778:84—94.

9. Sala M, Sunyer J, Otero R, Santiago-Silva, Camps C, Grimalt JO. Organochlorine compounds concentrations in the serum of inhabitants living near an electrochemical factory. Occup Environ Med 1998;56:152-8.

10. Wallace L, Buckley T, Pellizzari E, Gordon S. Breath measurements as volatile organic compound biomarkers. Environ Health Perspect 1996;104 Suppl 5:861—9.

11. Thompson K, Evans J. Workers' breath as a source of perchloroethylene (Perc) in the home. J Expo Anal Environ Epidemiol 1993;3(4):417-30.

12. World Heatlh Organization. Hexachlorobenzene. Geneva: World Heath Organization, 1997. Environmental Health Criteria, 195.

13. van der Ven $\mathrm{K}$, van der Ven $\mathrm{H}$, Thibold A, Baner O, Kaisi M, Mbura J, et al. Chlorinated hydrocarbon content of fetal and maternal body tissues and fluids in full term pregnant women: a comparison of Germany versus Tanzania. Hum Reprod 1992;7 suppl 1:95-100.

14. Needham LL, Burse VW, Head SL, Korver MP, McClure PC, Andrews JS, et al. Adipose tissue/serum partitioning of chlorinated hydrocarbon pesticides in humans. Chemosphere 1990;20:975-80.

Received for publication: 6 November 1998 